"Przegląd Prawa Konstytucyjnego"

Nr $4(16) / 2013$

\title{
Recenzja
}

\section{Eukasz Machaj, Wypowiedzi symboliczne w orzecznictwie Sądu Najwyższego USA, Wrocław 2011, Wydawnictwo Uniwersytetu Wrocławskiego (Prawnicza i Ekonomiczna Biblioteka Cyfrowa), ss. 492}

Wybór tematu należy ocenić z uznaniem. Jest to zagadnienie tzw. wypowiedzi symbolicznych, czyli zachowań ekspresyjnych w orzecznictwie Sądu Najwyższego Stanów Zjednoczonych wydanym na podstawie I i XIV Poprawki do Konstytucji, zabraniających władzom państwowym na wszystkich szczeblach ograniczania wolności słowa. Judykatura ta odzwierciedla wzrost roli sądownictwa w kształtowaniu porządku społecznego, który prowadzi do istotnego ograniczenia swobody manewru przysługującego władzy ustawodawczej. Ilustruje też ona, jak na fundamencie zbudowanym z ledwie kilku słów SN potrafi wykreować wieloaspektową doktrynę prawną, obejmującą szereg zasad i wyjątków oraz odnoszącą się do mnogości zróżnicowanych stanów prawnych oraz faktycznych. Ponadto poszanowanie wolności wypowiedzi jest jedną z podstawowych reguł aksjologicznych, które winny być respektowane w liberalnych demokracjach. Tymczasem w ostatnich latach w polskiej debacie publicznej głos zwolenników szerokiego rozumienia tego prawa rozbrzmiewa wyraźnie słabiej aniżeli bezpośrednio po przełomie ustrojowym z 1989 r. Coraz częściej zaczyna dominować optyka restrykcyjna, akcentująca etyczną konieczność podejmowania przez aparat państwa działań represjonujących głoszenie „niemoralnych” bądź „fałszywych” wypowiedzi. Natomiast judykatura SN USA, apoteozująca przestrzeganie wolności słowa i akcentująca aksjologiczną doniosłość takiego postępowania, dostarcza tu intelektualnej amunicji pozwalającej na skuteczne przeciwstawianie się wspomnianej optyce. 
Autor dokonał poważnego wysiłku, o czym świadczy nie tylko objętość jego rozprawy i pokaźna bibliografia, której wykaz liczy sobie 44 strony (sic!). Można jednoznacznie powiedzieć, że sięgnął do najważniejszych prac na interesujący go temat. Do tego dochodzi jeszcze wykorzystanie odnośnego orzecznictwa federalnego SN, które w tej materii jest nader bogate. W przeciwnym razie trudno byłoby mówić o rzetelnym opracowaniu tematu.

Recenzowana monografia składa się ze wstępu, trzech rozdziałów, zakończenia, orzecznictwa i bibliografii. $\mathrm{W}$ rozdziale pierwszym Autor przedstawia krótkie omówienie pozycji ustrojowej SN Stanów Zjednoczonych, interpretację I Poprawki do Konstytucji tego kraju oraz charakterystykę relacji między ekspresją werbalną a symboliczną. W rozdziale drugim znajdujemy analizę orzeczeń, w których $\mathrm{SN}$ - rozważając problem konkretnego rodzaju ekspresji symbolicznej - posłużył się dyrektywami wypracowanymi bezpośrednio w odniesieniu do komunikacji werbalnej. Natomiast w rozdziale trzecim Autor przedstawia sformułowany przez SN test O’Briena, który jest instrumentem wykorzystywanym zasadniczo $\mathrm{w}$ odniesieniu do unormowań dotyczących ekspresji symbolicznej. Ów test nakazuje rozróżnić sytuację, w której badane przez SN unormowanie jest wymierzone w ekspresję symboliczną, od okoliczności, w których regulacja dotyczy wszystkich zachowań danego rodzaju, niezależnie od obecności w nich konstytucyjnie istotnego potencjału ekspresyjnego. Następnie natrafiamy na „Zakończenie", które w istocie jest podsumowaniem książki, co i słusznie. Zakończenia mają bowiem sens głównie w powieściach.

Struktura pracy jest więc spójna i logiczna. Wielką - jeśli nie największą zasługę Autora upatruję w tym, że z tego istnego zalewu publikacji zdołał wyłowić zagadnienia najważniejsze i odpowiednio je uporządkować.

Pozytywnie oceniam też osiągnięty rezultat badawczy. Autor postawił sobie za cel rozwiązanie określonego problemu naukowego i cel ten osiągnął. Po lekturze jego dysertacji czytelnik rzeczywiście może wykazać się dogłębną wiedzą na temat wypowiedzi symbolicznych w judykaturze SN USA. Autor również przekonująco udowodnił, że potrafi panować nad ogromem materiału. Na podkreślenie zasługuje przy tym sumienność - w całej książce niemalże brak „literówek” - jak również autentyczna pasja badawcza.

Za szczególnie warte odnotowania osiągnięcia naukowe Autora należy uznać m.in. w pełni samodzielne i oryginalne rozważania widniejące 
na s. 321-330 oraz 435-442. Do tego należy dodać następujące wnioski: po pierwsze, że zakres wolności słowa zawarty w I Poprawce jest bardzo szeroki, zarówno w ujęciu absolutnym, jak i komparatystycznym. Po wtóre, że SN generalnie aprobuje kwalifikowanie różnorakich zachowań niewerbalnych jako desygnatu użytego w I Poprawce terminu „słowo”. Po trzecie, że możliwe jest skonstruowanie na podstawie orzeczeń SN teoretycznego modelu określającego odpowiedni przebieg procesu sądowego w sprawach dotyczących ograniczenia swobody wypowiedzi symbolicznych. Po czwarte, że w owych orzeczeniach w sprawach dotyczących klauzuli wolności słowa coraz większą rolę odgrywa reguła neutralności światopoglądowej państwa. Po piąte, że test O’Briena wydaje się rozsądnym kompromisowym rozwiązaniem dylematów dotyczących kwestii nakładania ograniczeń na wypowiedzi symboliczne. Po szóste, że SN odegrał kluczową rolę w ukształtowaniu obowiązującego dziś w Stanach Zjednoczonych modelu ochrony wolności słowa. Obserwacja ta jest trafna szczególnie w kontekście wypowiedzi symbolicznych itp.

Co się tyczy walorów naukowych recenzowanej monografii, to trudno oczywiście oczekiwać, żeby była ona wolna od wszelkich zastrzeżeń. I tak, wstęp można było poddać kuracji odchudzającej (s. 7-11). Po co bowiem rozpisywać się o tym, o czym Autor będzie pisać dalej - wystarczy trochę czytelniczej cierpliwości. Wstęp powinien zawierać jedynie dwa elementy: uzasadnienie wyboru tematu oraz założenia metodologiczne.

Wyznanie Autora, iż określenia „teoria”, „doktryna” i „koncepcja” będzie traktować jako synonimy (s. 13), jest wprawdzie prostoduszne, ale nie trafia do przekonania. Jest to przejaw zasugerowania się istną anglosaską terminologiczną niefrasobliwością. Dla dziennikarza tabloidu takie terminy faktycznie mogą się jawić jako synonimy, ale nie dla uczonego. Inny wydźwięk, choćby tylko intuicyjny, ma określenie np. „teoria Darwina”, a zgoła inny zdanie: „Na temat skoku na sklep GS dzielnicowy Kuś ma swoją teorię”.

Nie mniej prostoduszna jest też deklaracja, iż „słowo konstytucja i termin pierwsza poprawka konsekwentnie piszę małą literą" (s. 13, 15). Cóż, konsekwencja to rzecz chwalebna, ale nie akurat w tym przypadku. Pewnie, że inteligentny czytelnik będzie wiedzieć, że chodzi o amerykańską ustawę zasadniczą. Generalnie jednak „konstytucja” i „pierwsza poprawka” to jakaś 
tam konstytucja i jakaś tam pierwsza poprawka, jakich multum. Autor idzie tu pod prąd utartemu „uzusowi”.

Owo podążanie pod prąd widać też w innych kwestiach. Po pierwsze, ogólnie przyjęto (tak w nauce amerykańskiej, jak i polskiej), że sygnatury sprawy podaje się tak, np. Chaplinsky v. New Hampshire, 315 U.S. 568 (1942); Autor natomiast przytacza je tak - Chaplinsky vs. New Hampshire, 315 U.S. Reports 568. Po drugie, „ordynans” to nieszczególnie zaszczytna funkcja w wojsku i jej angielskim odpowiednikiem jest słowo orderly. Natomiast termin ordonnance to nic innego, jak nasz poczciwy ordonans względnie zarządzenie. Po trzecie, concurring opinion to nie jakaś „opinia wspomagająca”, tylko „opinia zbieżna”.

Wszystko to są wszak grzechy lekkie, z których łatwo Autora rozgrzeszyć.

Dużo jednak trudniej rozgrzeszyć Autora z języka książki, a to z tej przyczyny, że rzecz została napisana po prostu... niemożebnie.

Owszem, materie, które Autor omawia, do łatwych nie należą. Cała jednak sztuka w tym, by o rzeczach trudnych pisać językiem prostym, a nie jeszcze trudniejszym. Autor uległ tu złudzeniu - częstemu wśród młodych badaczy - że im bardziej „uczenie” napisze swe dzieło, to tym lepiej. Tymczasem jest dokładnie odwrotnie. Nie znaczy to, że Autor nie potrafi tak pisać - w książce można uświadczyć całe fragmenty zupełnie pod tym względem „koszerne” - tyle, że nie chce.

Dla języka recenzowanej monografii charakterystyczne jest przede wszystkim nadużywanie anglicyzmów, wielokrotnie przewyższające dopuszczalną miarę. Zamiast pisać po ludzku m.in. „zastosowanie, zgodny, uleganie, ochrona, zakładać, ocena, odrzucenie, włączenie, zakaz, stanowić, ustalać, stwierdzać, oznaczać, skład”, Autor wyłącznie używa określeń „aplikacja, kompatybilny, deferencja, protekcja, fundować, ewaluacja, refutacja, inkluzja, proskrypcja, konstytuować, stypulować, statuować, denotować, kompozycja”. Nie podaję numerów stron, bo takie „kwiatki” występują średnio po 1-2 na każdej stronie.

Wszystkie te językowe potworki zadają gwałt mowie ojczystej i w zależności od temperamentu recenzenta mogą zostać uznane albo za język w najwyższym stopniu hermetyczny, albo zgoła bełkotliwy. Po uraczeniu taką porcją „makaronizmów” recenzenta nachodzi refleksja, po co się właściwie Autor trudził, skoro mógł po prostu we wszystkich angielskich rzeczowni- 
kach i czasownikach pozmieniać końcówki na polskie, albo jeszcze lepiej najzwyczajniej w świecie napisać swą pracę po angielsku.

Już dużo mniejszym grzechem jest operowanie określeniem „dywagacje”, które oznacza tyle, co brednie, ale mało kto o tym wie. Trafia się accusativus iudaicus (m.in. na s. 123 ,istotnym jest”). Autor nie może się przy tym zdecydować, czy pisać „konsens”, czy „konsensus”. Można również natrafić na nieszczęsny „zapis” czy na modne dziś „Zagłosować”. To samo trzeba rzec o określeniu „najbardziej fundamentalny”, z czego wynika, że fundamentów może być co najmniej kilka. Autor nie stroni też od deklaracji w rodzaju „osobiście sądzę” czy „osobiście uważam”; głupie pytanie - czy można sądzić (uważać) nieosobiście?

Jeszcze mniejszym grzechem pozostaje zwrot „pełnić rolę”, skoro rolę można tylko grać. Niemniej ostatnio się dowiedziałem, że poloniści uznają ów dziwoląg za tzw. normę użytkową. Rzecz dziwna, bo jest to wyraźny rusycyzm (ispotniat' rol').

Kontrast dla lingwistycznej awangardy Autora tworzy maniera wyłącznego posługiwania się kilkoma archaizmami. Miast pisać po ludzku „takie”, „jednak”, „nie doceniać”, Autor stale pisze „takowe”, „jednakowoż”, „zapoznawać”. Razi kolokwializm „podpadać pod przepis”.

Niezdecydowanie Autor przejawia także w kwestii, czy opisowe przypisy podawać w języku polskim czy angielskim. W efekcie mamy i jedno, i drugie. Tymczasem powinien tu znaleźć zastosowanie niemal wyłącznie język ojczysty. Nikt bowiem nie ma obowiązku znać angielskiego. Sądziłem naiwnie, że maniera przytaczania cytatów - i to w tej samej książce - i w języku angielskim, i niemieckim, i francuskim, etc. wyszła $z$ użycia jeszcze przed II wojną światową. Czytelnik nie musi być poliglotą; no, chyba że Autor pisze tylko dla recenzentów.

Lekturę znacznie utrudniają długachne akapity, skutkiem czego niełatwo się przez nie przebić. Winno ich być od 1 do 3 na stronie, a Autor potrafi je ciągnąć nawet na stron cztery (m.in. 43-46, 203-207).

$\mathrm{Na}$ usprawiedliwienie Autora można rzec, że nie popisał się tu recenzent wydawniczy; może pracował społecznie? Poza tym w „stopce” książki nigdzie nie widać redaktora. Czyżby tzw. e-monografie obywały się bez nich?

Mimo to moje pretensje do Autora mają charakter drugorzędny. Trudno bowiem kwestie lingwistyczne traktować jako pierwszorzędne w prawni- 
czych pracach naukowych. Nie są więc w stanie podważyć pochlebnej oceny recenzowanej książki, która stanowi oryginalny wkład do polskiej ustrojowej amerykanistyki.

Ryszard M. Małajny Uniwersytet Śląski w Katowicach 